\title{
Monoclonal antibodies against extra small virus show that it co-localizes with Macrobrachium rosenbergii nodavirus
}

\author{
Siwaporn Longyant ${ }^{1}$, Saengchan Senapin ${ }^{2,3}$, Sirijantra Sanont $^{1}$, Pradit Wangman $^{1}$, \\ Parin Chaivisuthangkura ${ }^{1}$, Sombat Rukpratanporn ${ }^{4}$, Paisarn Sithigorngul ${ }^{1, *}$ \\ ${ }^{1}$ Department of Biology, Srinakharinwirot University, Bangkok 10110, Thailand \\ ${ }^{2}$ CENTEX Shrimp, Mahidol University, Bangkok 10400, Thailand \\ ${ }^{3}$ National Center for Genetic Engineering and Biotechnology (BIOTEC), Pathumthani 12120, Thailand \\ ${ }^{4}$ Center of Excellence for Marine Biotechnology at Chulalongkorn University, \\ National Center for Genetic Engineering and Biotechnology (BIOTEC), Bangkok 10330, Thailand
}

\begin{abstract}
The capsid protein (CP) gene of extra small virus (XSV) expressed in Escherichia coli as a $42 \mathrm{kDa}$ glutathione S-transferase (GST)-fusion protein (GST-XCP) or a $20 \mathrm{kDa} \mathrm{His}_{6}$-fusion protein $\left(\mathrm{His}_{6}-\mathrm{XCP}\right)$ were purified by sodium dodecyl sulfate polyacrylamide gel electrophoresis (SDS-PAGE), combined, and used to immunize Swiss mice to produce monoclonal antibodies (MAbs). Using dot blot, Western blot, and immunohistochemistry (IHC) methods, 4 MAbs specific to the XSV CP detected XSV in the freshwater prawn Macrobrachium rosenbergii without crossreaction to host proteins or to proteins of Macrobrachium rosenbergii nodavirus (MrNV) or 5 of the most pathogenic viruses of penaeid shrimp. In dot blots, the combined MAbs could detect down to

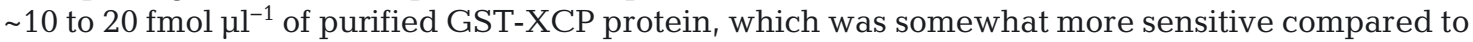
any single MAb. Used in conjunction with an MrNV-specific MAb, white tail disease (WTD) was diagnosed more effectively. However, the sensitivity at which the combined 4 MAbs detected XSV CP was 1000-fold lower than XSV RNA detected by RT-PCR. IHC analysis of $M$. rosenbergii tissue sections using the MAbs showed XSV infection to co-localize at variable loads with MrNV infection in heart and muscle cells as well as cells of connective tissues in the hepatopancreas. Since XSV histopathology remained prominent in tissues of some prawns in which MAb reactivity for MrNV was low compared to MAb reactivity for XSV, XSV might play some role in WTD severity.
\end{abstract}

KEY WORDS: Immunohistochemistry - Macrobrachium rosenbergii nodavirus - MrNV . Monoclonal antibody $\cdot$ Capsid protein $\cdot$ Western blot $\cdot$ Extra small virus $\cdot$ XSV

\section{INTRODUCTION}

Outbreaks of white tail disease (WTD) in hatcheryreared postlarvae (PL) of the giant river prawn Macrobrachium rosenbergii have occurred in many parts of the world including the West Indies (Arcier et al. 1999), Taiwan (Tung et al. 1999, Wang et al.
2008), China (Qian et al. 2003), India (Sahul Hameed et al. 2004), Thailand (Yoganandhan et al. 2006), and Australia (Owens et al. 2009). WTD is caused by Macrobrachium rosenbergii nodavirus (MrNV) and extra small virus (XSV) (Arcier et al. 1999, Qian et al. 2003), is characterized by whitened abdominal muscle, and can cause almost complete 
losses of PL in hatcheries and nursery ponds within $5 \mathrm{~d}$ of gross signs first appearing (Arcier et al. 1999). In muscle tissue affected by WTD, MrNV is always found in conjunction with XSV (Qian et al. 2003). MrNV is a small (27 nm diam.) non-enveloped icosahedral virus with a genome comprising 2 singlestranded RNAs $2.9 \mathrm{~kb}$ and $1.3 \mathrm{~kb}$ in length and a capsid comprised of a single $43 \mathrm{kDa}$ protein (Bonami et al. 2005). The XSV genome is a singlestranded RNA 796 nucleotides in length that encodes a 16-17 $\mathrm{kDa}$ capsid protein (CP). XSV is considered to be a satellite virus dependent on the MrNV RNA-dependent RNA polymerase for genome replication (Sri Widada \& Bonami 2004, Bonami et al. 2005).

Dot blot and in situ hybridization (Sri Widada et al. 2003, Hsieh et al. 2006, Wang et al. 2008), RT-PCR (Sri Widada et al. 2003, Sahul Hameed et al. 2004), multiplexed RT-PCR (Yoganandhan et al. 2005, Tripathy et al. 2006, Owens et al. 2009, Senapin et al. 2010, 2012), real-time RT-PCR (Zhang et al. 2006), and reverse transcription loop-mediated isothermal amplification (RT-LAMP) (Pillai et al. 2006, Haridas et al. 2010, Puthawibool et al. 2010) have been developed to detect MrNV and/or XSV RNA. While highly specific and sensitive, all of these molecular detection methods are quite complicated and expensive and thus not practical for pond-side detection of these viruses. Sandwich ELISA and other protein detection methods have also been developed using either polyclonal antibodies (Romestand \& Bonami 2003, Sahul Hameed et al. 2011) or monoclonal antibodies (MAbs) (Qian et al. 2006, Wangman et al. 2012) prepared to either native or recombinant MrNV proteins. Here we describe the preparation of MAbs to the XSV CP expressed in bacteria as 2 types of recombinant-fusion proteins and their use in various immunodetection methods to detect XSV in association with MrNV in Macrobrachium rosenbergii affected by WTD.

\section{MATERIALS AND METHODS}

\section{Virus preparation}

The presence of MrNV and XSV in 2 batches of Macrobrachium rosenbergii PL showing gross signs of WTD and obtained from hatcheries in Chachoengsao Province, Thailand, was verified by RT-PCR (Senapin et al. 2012). Some PL from each batch were homogenized in $0.15 \mathrm{M}$ phosphate-buffered saline $\left(\mathrm{PBS}_{i} \mathrm{pH}\right.$ 7.2) at approximately 1:10 (v:v) and cen- trifuged at $3000 \times g$ for $30 \mathrm{~min}$, and aliquots of the supernatant were stored at $-70^{\circ} \mathrm{C}$. The remaining PL from each batch were fixed in Davidson's fixative and processed for histology. Uninfected M. rosenbergii collected from elsewhere were used as negative controls in various tests.

\section{RNA extraction}

WTD-affected Macrobrachium rosenbergii were homogenized in lysis buffer (50 mM Tris- $\mathrm{HCl}, \mathrm{pH}$, $100 \mathrm{mM}$ EDTA, $50 \mathrm{mM} \mathrm{NaCl}$, $2 \%$ sodium dodecyl sulfate [SDS]), and RNA was extracted from $200 \mu \mathrm{l}$ homogenate using a High Pure viral nucleic acid kit (Roche Molecular Biochemicals) using the protocol described by the manufacturer.

\section{XSV CP gene expression constructs}

Random-primed cDNA was synthesized from RNA of XSV-infected prawns using the Superscript 1-step RT-PCR system (Invitrogen) and amplified by PCR using the primers XSVF70 (5'-CGG GAT CCT CTA ATC TCA TTC CTT AC-3') and XSVR (5'-CGT CGA CTT ACT GTT CGG AGT CCC AAT ATG-3') containing 5'-terminal restriction endonuclease sites (underlined) and designed to amplify a portion of the XSV CP gene devoid of its Nterminal hydrophobic transmembrane region. The thermal cycling conditions used were $50^{\circ} \mathrm{C}$ for $30 \mathrm{~min}, 95^{\circ} \mathrm{C}$ for $5 \mathrm{~min}$, and $4^{\circ} \mathrm{C}$ for $5 \mathrm{~min}$, followed by 35 cycles of $95^{\circ} \mathrm{C}$ for $1 \mathrm{~min}, 55^{\circ} \mathrm{C}$ for $45 \mathrm{~s}$, and $72^{\circ} \mathrm{C}$ for $1 \mathrm{~min}$, with a final extension at $72^{\circ} \mathrm{C}$ for $15 \mathrm{~min}$. The $471 \mathrm{bp}$ PCR product was purified and digested with BamHI and SalI, cloned into these sites in the pGEX-6P-1 expression vector (Amersham Bioscience), and transformed into Escherichia coli strain BL21. The continuity of the glutathione $\mathrm{S}$-transferase (GST)-fusion protein (GST-XCP) open reading frame in selected recombinant plasmids was verified by DNA sequencing. A full-length XSV CP gene coding sequence was amplified similarly using the primers XSV-F (5'-GGA ATT CCA TAT GAA TAA GCG CAT TAA TAA-3') and XSVR (5'-CGC GGA TCC TTA CTG TTC GGA GTC CCA ATA-3I), and the 538 bp amplicon was digested with NdeI and BamHI and cloned into these sites in pET15b (Novagen) vector, and the continuity of $\mathrm{His}_{6}$-XCP fusion protein open reading frame of selected recombinant plasmids was verified by DNA sequencing. 


\section{XCP fusion protein expression and purification}

Escherichia coli strain BL21 transformed with either plasmid pGEX-6P-1-XCP or pET15b-XCP was cultured in Luria-Bertani (LB) broth to the exponential phase before recombinant protein expression was induced using $1 \mathrm{mM}$ isopropyl- $\beta$-D-thiogalactopyranoside (IPTG). After $4 \mathrm{~h}$ additional growth, bacteria were collected by centrifugation at $3000 \times g$ for $20 \mathrm{~min}$. Bacterial pellets were suspended in buffer (100 $\mathrm{mM} \mathrm{NaH}_{2} \mathrm{PO}_{4}, 10 \mathrm{mM}$ Tris- $\mathrm{HCl}$, and $8 \mathrm{M}$ urea, $\mathrm{pH}$ 8) containing $1 \mathrm{mM}$ phenylmethylsulfonyl fluoride (PMSF) and sonicated until the lysate cleared. Proteins in the lysate were separated by SDS polyacrylamide gel electrophoresis (SDS-PAGE) using a $15 \%$ gel. After treatment of the gel in $0.3 \mathrm{M} \mathrm{KCl}$, the GST-XCP and $\mathrm{His}_{6}$-XCP recombinant fusion proteins were excised, placed in dialysis bags, eluted with a Transblot apparatus (BioRad) at $70 \mathrm{~V}$ for $6 \mathrm{~h}$, dialyzed, and concentrated using a Savant centrifuge vacuum concentrator. The concentration of the purified recombinant protein solutions was determined by Bradford assay (Bradford 1976) and following dilution to $0.5 \mathrm{mg} \mathrm{ml}^{-1}$, small aliquots of each dilution were stored at $-70^{\circ} \mathrm{C}$.

\section{Mouse immunization and MAb production}

Purified GST-XCP and $\mathrm{His}_{6}-\mathrm{XCP}$ proteins mixed 1:1 were emulsified in Freund's complete adjuvant (FCA) at a 1:1 ratio and injected into the intraperitoneal cavity of 4 Swiss mice at $0.05 \mathrm{mg}$ protein per mouse. Mice were injected similarly 3 more times at 2 wk intervals using the same proteins emulsified in Freund's incomplete adjuvant (FIA). One week after the final injection, mice were bled to collect antisera that were tested for reactivity to the GST and to the GST-XCP and $\mathrm{His}_{6}$-XCP fusion proteins by SDS-PAGE and Western blotting. The mouse with the highest antibody levels was subsequently boosted again 3 d before hybridoma production. All procedures using mice adhered to regulations described in Ethical Principles and Guidelines for the Use of Animals for Scientific Purposes, The National Research Council Thailand. The P3X myeloma cell fusion protocol used to produce MAbs was that developed by Köhler \& Milstein (1976) modified as described by Mosmann et al. (1979). Cell fusion products were plated onto thirty 96-well microculture plates and positive cul- tured fluids were identified initially by dot blot using GST as well as the GST-XCP:His 6 -XCP protein mixture and subsequently by Western blotting and immunohistochemistry (IHC). Cell clones were selected and recloned from immunoreactive cultures using the limiting dilution method and stored in liquid nitrogen.

\section{Dot blot method}

Lysates of Escherichia coli strain BL21 expressing GST, GST-XCP, or $\mathrm{His}_{6}-\mathrm{XCP}$, and homogenates of uninfected or WTD-affected prawn tissue were applied to nitrocellulose membranes (1 $\left.\mu \mathrm{spot}^{-1}\right)$, baked at $60^{\circ} \mathrm{C}$ for $10 \mathrm{~min}$, and incubated in hybridoma-conditioned culture medium diluted 1:20 in $1 \%$ blocking solution (1\% nonfat dry milk, $0.1 \%$ Triton X-100 in PBS) for $4 \mathrm{~h}$. After extensive washing in $0.5 \%$ blocking solution $(4 \times 15 \mathrm{~min})$, membranes were incubated in horseradish peroxidaselabeled goat anti-mouse gamma immunoglobulin heavy and light chain-specific antibody (GAMHRP, Bio-Rad) diluted 1:1500 for $3 \mathrm{~h}$. Membranes were then washed in blocking solution for $4 \times$ $15 \mathrm{~min}$ before being incubated for $5 \mathrm{~min}$ in a substrate solution $(0.03 \%$ diaminobenzidine [DAB], $0.006 \% \mathrm{H}_{2} \mathrm{O}_{2}$, and $0.05 \% \mathrm{CoCl}_{2}$ in PBS) for color development (Sithigorngul et al. 2002). To determine the detection limit of the XSV MAbs in dot blots, serial dilutions of purified GST-XCP protein in PBS were spotted onto nitrocellulose membranes and detected as described in this section.

\section{Western blot method}

Lysates used in dot blots were also separated by SDS-PAGE in a $15 \%$ gel electrophoresed at $60 \mathrm{~V}$ for $3 \mathrm{~h}$ as described by Laemmli (1970). Proteins in one gel section were stained using Coomassie Brilliant Blue R-250, and proteins in the other section were transferred onto a nitrocellulose membrane using a Transblot apparatus (BioRad). Membranes were incubated in $1 \%$ blocking solution for $10 \mathrm{~min}$ before adding MAbs or mouse anti-XCP protein antiserum (preabsorbed with Escherichia coli lysate containing GST) for $3 \mathrm{~h}$. After extensive washing in $0.5 \%$ blocking solution, membranes were incubated with GAMHRP dilution 1:1500 for $4 \mathrm{~h}$, and washed extensively again before being incubated in a substrate solution $\left(0.03 \% \mathrm{DAB}, 0.006 \% \mathrm{H}_{2} \mathrm{O}_{2}, 0.05 \% \mathrm{CoCl}_{2}\right.$ in $\mathrm{PBS}$ ) for color development. 


\section{IHC method}

WTD-affected Macrobrachium rosenbergii PL fixed in Davidson's fixative solution for $24 \mathrm{~h}$ were processed into paraffin and serial tissue sections ( $8 \mu \mathrm{m}$ thick) and processed for indirect immunoperoxidase staining. Briefly, each section was covered for $12 \mathrm{~h}$ with each MAb diluted to 1:100 and then with GAM-HRP diluted to $1: 1000$ in $10 \%$ calf serum in PBS. Color was developed by incubating sections in $0.03 \%$ DAB and $0.006 \% \mathrm{H}_{2} \mathrm{O}_{2}$ in PBS. Sections were counterstained with hematoxylin and eosin $\mathrm{Y}$ (H\&E), dehydrated in graded series of ethanol concentration, cleared in xylene, and mounted in Permount (Sithigorngul et al. 2002). Positive reactions appeared as brown coloration against pink cytoplasm and purple nuclei. To examine if XSV co-localized with MrNV, serial histological sections of 18 WTD-affected PL processed were detected using the XSV-1 MAbs (the present study) in combination with MAb MrNV-12 (Wangman et al. 2012).

\section{Determining MAb class and subclass}

Classes and subclasses of the mouse immunoglobulins produced by the hybridomas were determined by sandwich ELISA using Mouse MonoAb ID Kit (Zymed).

\section{MAb cross-reactivity testing}

Histological tissue sections of penaeid shrimp infected with $P$ naeus monodon densovirus (PmDNV), Penaeus monodon nucleopolyhedrovirus (PemoNPV), Taura syndrome virus (TSV), infectious myonecrosis virus (IMNV), white spot syndrome virus (WSSV), and yellow head virus (YHV) were examined by IHC using the XSV-specific MAbs. Results were compared to IHC tests performed using MAbs specific to PmDNV (Rukpratanporn et al. 2005), TSV (Longyant et al. 2008), IMNV (Kunanopparat et al. 2011), WSSV (Chaivisuthangkura et al. 2004), YHV (Sithigorngul et al. 2002), and PemoNPV (Boonsanongchokying et al. 2006).

\section{Comparison of dot blot and RT-PCR for detecting XSV}

Tissue homogenates from WTD-affected prawns serially diluted in homogenates from an unaffected prawn were processed to detect XSV by dot blot and RT-PCR. In dot blots, XSV MAbs and MAb combinations as well as an MrNV MAb (Wangman et al. 2012) were tested, and the lowest dilution of homogenate showing color development was taken as the end point. Dot blots were also performed using an Escherichia coli lysate containing GST-XCP diluted similarly. Total RNA isolated from the same prawn homogenate and serially diluted in total RNA isolated from an unaffected prawn was tested by RTPCR using primers XSVF70 and XSVR as described in 'XSV CP gene expression constructs' above.

\section{RESULTS}

\section{XSV CP gene expression}

The recombinant $42 \mathrm{kDa}$ GST-XCP and $20 \mathrm{kDa}$ $\mathrm{His}_{6}$-XCP fusion proteins expressed in Escherichia coli were resolved by SDS-PAGE (Fig. 1). Recombinant protein bands excised from the gel and eluted from gel pieces were also analyzed to demonstrate their effective recovery, purity, and integrity (Fig. 1).

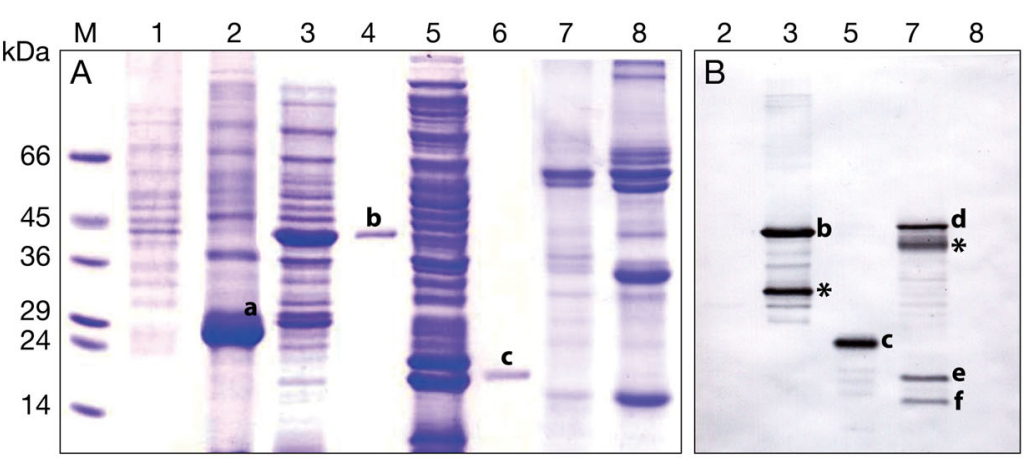

Fig. 1. Escherichia coli and Macrobrachium rosenbergii. SDS-PAGE and Western blotting. Lysates of E. coli strain BL21 without plasmid (1) or containing plasmids pGEX-6P-1 (2), pGEX-6P-1-XCP (3), or pET15b-XCP (5), and samples of purified GST-XCP (4), purified $\mathrm{His}_{6}$-XCP (6) or homogenates from white tail disease-affected prawns (7) or uninfected postlarvae (8) were electrophoresed in $15 \%$ polyacrylamide gel. (A) Part of the gel was stained with Coomassie Brilliant Blue, and (B) another part of the gel was transferred to nitrocellulose membrane and treated with monoclonal antibodies XSV-1 + MrNV-12. M: standard marker proteins; a: glutathione S-transferase (GST) $(26 \mathrm{kDa}) ; \mathrm{b}:$ GST-XCP $(43 \mathrm{kDa}) ; \mathrm{c}: \mathrm{His}_{6}-\mathrm{XCP}(20 \mathrm{kDa})$; d: natural Macrobrachium rosenbergii nodavirus (MrNV) capsid protein (42 kDa); e and f: natural extra small virus (XSV) capsid proteins (17 and $16 \mathrm{kDa}$, respectively); *: degradation products or partial synthesis proteins 


\section{MAb production}

After multiple injections of 4 mice with a 1:1 mixture of the gel-purified GST-XCP and $\mathrm{His}_{6}$-XCP proteins, antiserum from all mice was found to react with GST$\mathrm{XCP}, \mathrm{His}_{6}-\mathrm{XCP}$, and XSV protein from homogenates of WTD-affected prawns. However, antiserum from only 1 mouse was found to be strongly immunoreactive based on its ability to detect GST-XCP, $\mathrm{His}_{6}-\mathrm{XCP}$, and double bands of native XSV CP when diluted 1:10 000. This mouse was thus selected as the spleen donor to produce hybridomas. In total, 1600 microculture wells containing hybridoma cells were obtained, with culture fluid from $\sim 20$ wells binding GST$\mathrm{XCP}$ and $\mathrm{His}_{6}$-XCP in initially screens. After further screening of culture fluid from clones derived from these wells by dot blot and Western blot, and by IHC with tissue sections from WTD-affected prawns, 4 MAbs with high specificity for XSV CP were selected from established hybridoma cell lines. MAbs were determined to be from the immunoglobulin G (IgG) subclasses IgG1, IgG2a, or IgG2b (Table 1).

\section{MAb specificity}

None of the 4 XSV CP-specific MAbs reacted with Escherichia coli proteins, E. coli-expressed GST, or tissue homogenates from uninfected prawns in either dot blots (Fig. 2) or Western blots (Fig. 1). All 4 MAbs bound to GST-XCP and $\mathrm{His}_{6}$-XCP and to double bands (16 kDa and $17 \mathrm{kDa}$ ) on native XSV CP present in tissue homogenates from WTD-affected prawns (Fig. 1B). In comparison to these 4 MAbs, a MAb specific to the MrNV CP (MrNV-12; Wangman et al. 2012) reacted more strongly with tissue homogenates from WTD-affected prawns in both dot blots and Western blots (Figs. 1B \& 2). By IHC, all 4 XSV CP MAbs reacted with muscle tissue and with loose connective tissues in the hepatopancreas and

Table 1. Characterization of monoclonal antibodies (MAbs) specific to extra small virus (XSV). IgG: immunoglo-

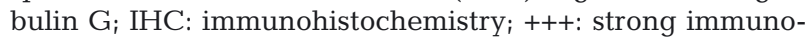
reactivity

\begin{tabular}{|lcccc|}
\hline MAb (isotype) & $\begin{array}{c}\text { Sensitivity } \\
\left(\mathrm{fmol} \mathrm{ll}^{-1}\right)\end{array}$ & $\begin{array}{c}\text { Western } \\
\text { blot }\end{array}$ & IHC & $\begin{array}{c}\text { Cross- } \\
\text { reactivity }\end{array}$ \\
\hline XSV-1 (IgG2b) & 10 & +++ & +++ & None \\
XSV-8 (IgG2a) & 20 & +++ & +++ & None \\
XSV-10 (IgG1) & 20 & +++ & +++ & None \\
XSV-17 (IgG2b) & 20 & +++ & +++ & None \\
\hline
\end{tabular}
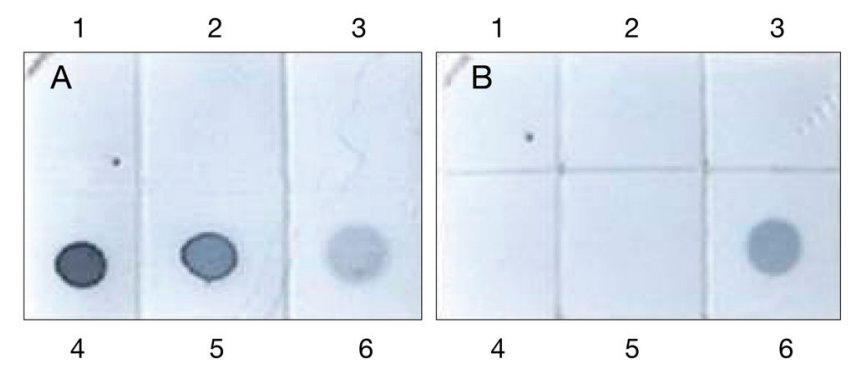

Fig. 2. Escherichia coli and Macrobrachium rosenbergii. Dot blot analysis of monoclonal antibodies (MAbs). Lysates of E. coli strain BL21 without plasmid (1) or containing plasmids pGEX-6P-1 (2), pET15b-XCP (4), or pGEX-6P-1-XCP (5), and homogenates from uninfected (3) or white tail disease-affected (6) postlarval prawns were spotted $\left(1 \mu \mathrm{l} \mathrm{spot}{ }^{-1}\right)$ onto a nitrocellulose membrane and treated with MAbs (A) XSV-1 or (B) MrNV-12

in the heart of WTD-affected prawns (Fig. 3). None of the MAbs exhibited cross-reactivity to tissues from uninfected Macrobrachium rosenbergii prawns or penaeid shrimp infected with IMNV, WSSV, YHV, TSV, PmDNV, or PemoNPV (data not shown).

\section{Co-localization of XSV and MrNV}

IHC of consecutive tissue sections from 18 WTDaffected prawns using XSV-specific MAb XSV-1 and the MrNV-specific MAb MrNV-12 showed that 3 reacted with XSV-1 and all 18 reacted with MrNV12. In some tissues of the $3 \mathrm{XSV}$-infected prawns, immunoreactions were equally intense for $\mathrm{MAb}$ XSV-1 and MAb MrNV-12, while in other tissues, XSV-1 reactions were either more or less intense than MrNV-12 reactions (Fig. 3). In all cases, XSV-1 and MrNV-12 reactions co-localized.

\section{Test sensitivity}

To test the detection sensitivity of XSV-specific MAbs, serial dilutions of GST-XCP protein were detected to a limit of $0.5 \mu \mathrm{g} \mathrm{ml}^{-1}$ with MAb XSV-1 and a limit of $1.0 \mathrm{\mu g} \mathrm{ml}^{-1}$ with MAbs XSV-8, XSV-10, and XSV-17, equivalent to $10-20 \mathrm{fmol}^{\mu l^{-1}}$ or $0.5-1 \mathrm{ng}$ protein $\mathrm{\mu l}^{-1}$. However, in dot blots using tissue homogenates of WTD-affected prawns, the detection sensitivity of MAb XSV-1 was between 2- and 8-fold higher than any of the other $3 \mathrm{XSV}$ specific MAbs (Fig. 4A-D). Detection sensitivity was increased only slightly when MAbs XSV-8, XSV-10, and XSV-17 were combined (Fig. 4E) but resulted in 
a 2-fold increase when MAb XSV-1 was also included (Fig. 4F) compared to XSV-1 alone (Fig. 4A). The detection sensitivity of the combined XSV MAbs was comparable to MAb MrNV-12 (Fig. 4H), and when combined with the 4 XSV MAbs, its detection sensitivity increased 2-fold (Fig. 4G).

To compare the sensitivity of the MAb dot blot method with RT-PCR, RNA extracted from the same prawn homogenates used in dot blots was amplified. As shown in Fig. 5, it was still just possible to detect a $471 \mathrm{bp}$ RT-PCR product with $10^{-6}$ diluted RNA, thus making this method on the order of 1000 -fold more sensitive than detection of a XSV protein by dot blot using all 4 XSV MAbs combined (Fig. 4F).

\section{DISCUSSION}

Here, 4 MAbs generated from 2 forms of purified recombinant XSV CP expressed in Escherichia coli were assessed for their ability to detect XSV in Macrobrachium rosenbergii PL prawns affected by WTD. The MAbs, and particularly all 4 MAbs combined, were effective at detecting XSV using dot blot and Western blot methods as well as in histological sections of tissues by IHC. While antibody-based ELISA and Western blot methods have been reported to detect MrNV (Romestand \& Bonami 2003, Qian et al. 2006, Sahul Hameed et al. 2011) or XSV (Sahul Hameed et al. 2011), this is the first report of XSV
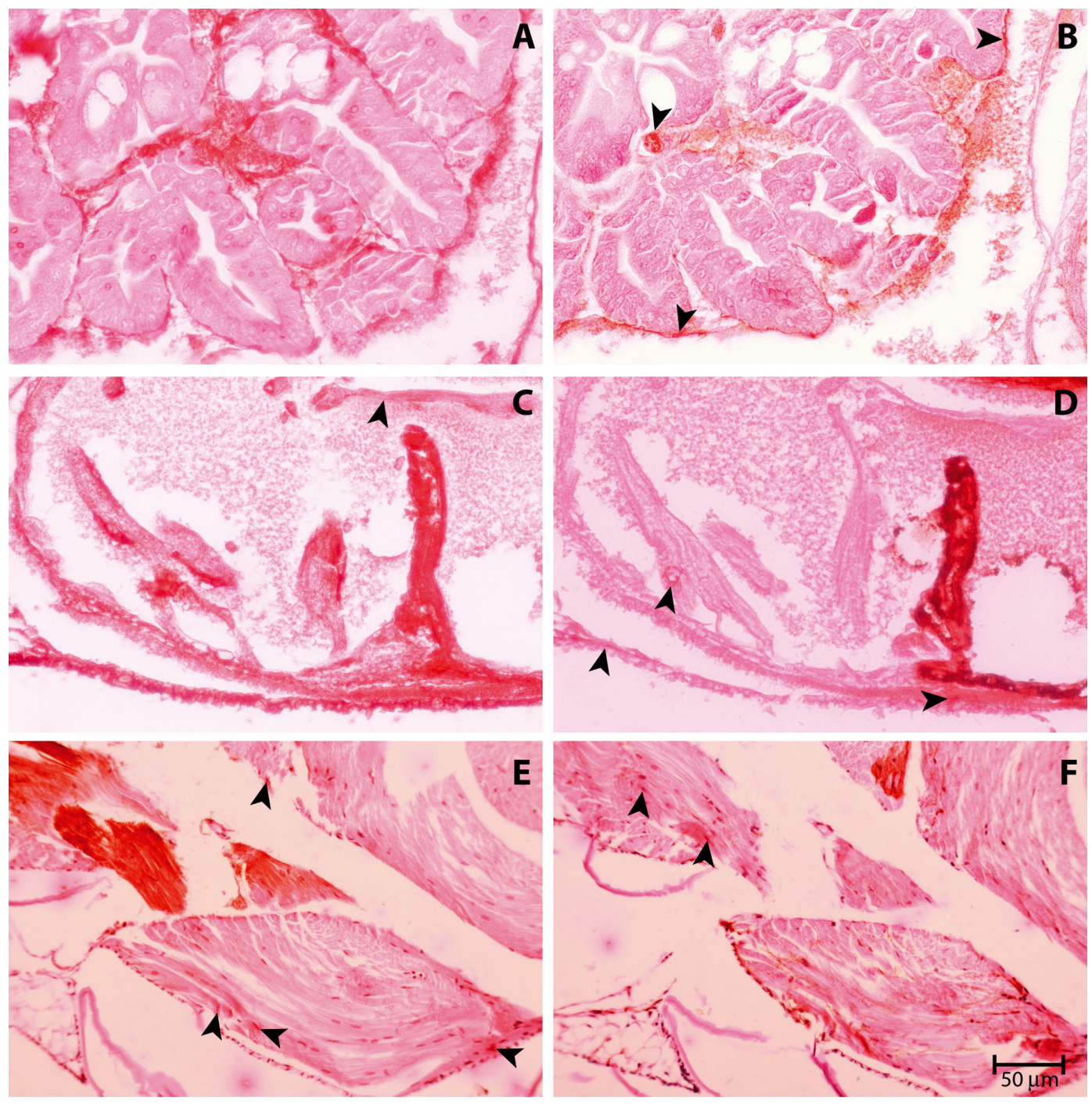

Fig. 3. Macrobrachium rosenbergii. Immunohistochemical analysis. Tissue sections from white tail disease-affected postlarvae were treated with $(A, C, E)$ monoclonal antibodies XSV-1 or $(B, D, F)$ MrNV-12 and counterstained with H\&E. Strong immunoreactivity was exhibited in (A) intertubular connective of hepatopancreas, (B) heart, and (C) striated muscle. Lightly immunoreactive areas are indicated (black arrowheads). Scale bar $=50 \mu \mathrm{m}$ for all panels 

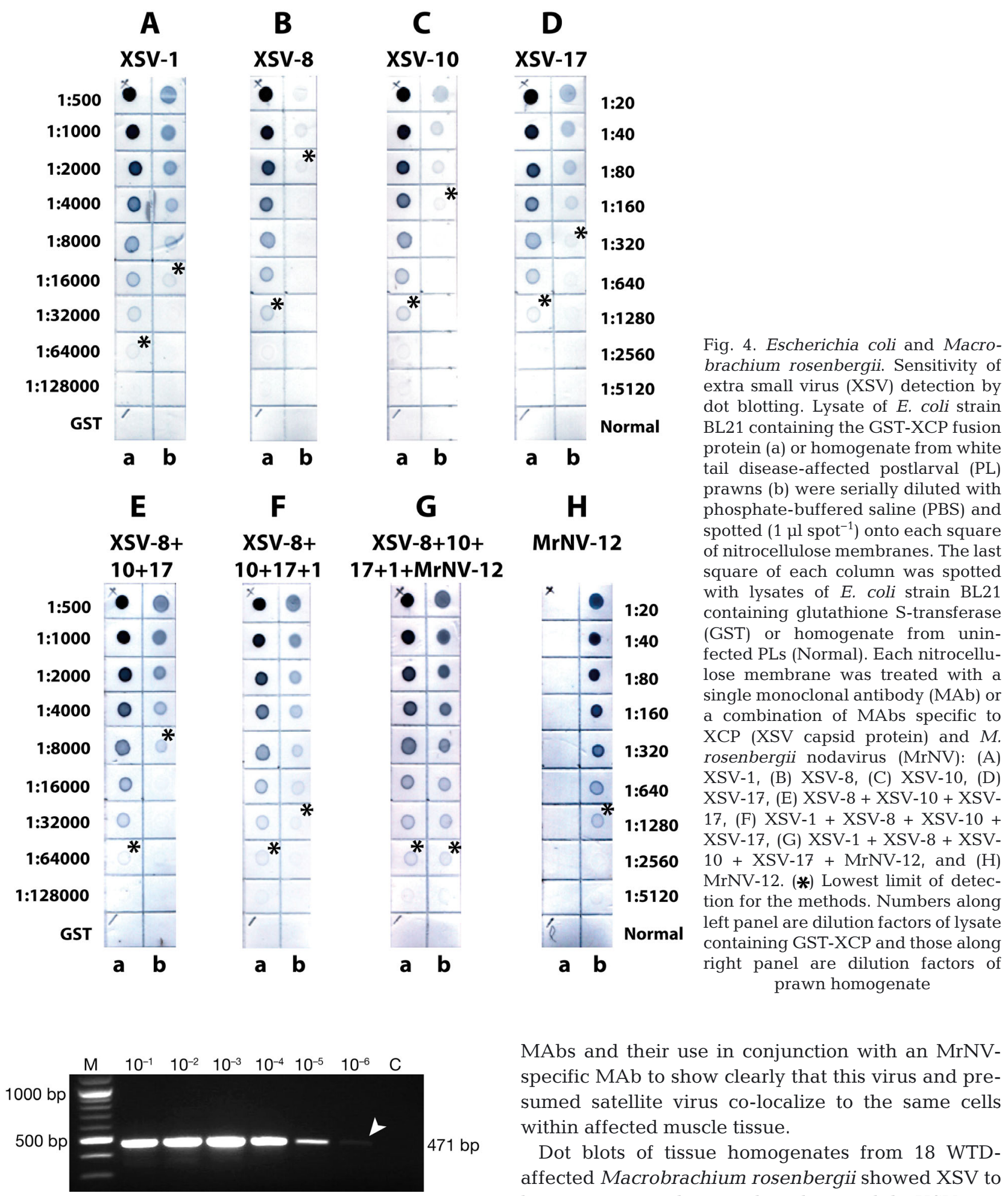

MAbs and their use in conjunction with an MrNVspecific MAb to show clearly that this virus and presumed satellite virus co-localize to the same cells within affected muscle tissue.

Dot blots of tissue homogenates from 18 WTDaffected Macrobrachium rosenbergii showed XSV to be present in only 3, and in these, while XSV was always found associated with MrNV, the detection

Fig. 5. Macrobrachium rosenbergii. RT-PCR analysis. The same sample of homogenate from white tail disease-affected postlarval prawns used for dot blotting was diluted from $10^{-1}$ to $10^{-6}$ and processed for RT-PCR. Lowest limit of detection for the methods is indicated (white arrowhead). M: DNA markers; C: negative control using distilled water intensity of XSV varied upward and downward in comparison to MrNV at different sites of infection and pathology within individuals. The low prevalence of XSV detected among the 18 WTD-affected 
prawns examined here is consistent with reports of RT-PCR testing which have found that, generally, XSV-positive individuals are also positive for MrNV but MrNV-positive prawns are not always infected with XSV at levels detectable by PCR (Tripathy et al. 2006, Yoganandhan et al. 2006, Bonami \& Sri Widada 2011). However, in unusual cases when XSV was detected in the absence of MrNV, it has been speculated that this might be due to MrNV existing at very low levels below that detectable by the method used (Senapin et al. 2010). Indeed, the IHC data obtained in the present study indicate that some tissues rich in XSV can be infected at only low loads with MrNV, suggesting that little MrNV replication might be needed to support extensive XSV replication. Moreover, tissues in which infection loads of XSV were apparently high when MrNV loads were low showed typical WTD histopathology. It is, therefore, possible that XSV might contribute to disease severity rather than being a benign companion virus.

Application of the XSV MAbs and an MrNV MAb to IHC showed the viruses to co-localize in striated muscle and in connective tissues or organs and appendages. XSV was infrequently detected in gill or heart muscle, but when detected in the heart, the IHC signal was distributed homogeneously with the MrNV IHC signal, similarly to striated muscle cells. This tissue infection pattern differs from viruses primarily causing muscle pathology in Penaeus vannamei shrimp, such as Penaeus vannamei nodavirus (PVNV) (Tang et al. 2007) and IMNV (Tang et al. 2005, Kunanopparat et al. 2011), which in heart tissue display an IHC signal limited to fixed hemocytes.

The quantities of XSV obtained in pooled samples in the present study were much lower than those obtained for MrNV due its less frequent infection, as seen by an approximately 2-fold lower detection limit for XSV than for MrNV by dot blotting (Fig. 4A,H) and Western blotting (Fig. 2). However, the detection of XSV via MAbs would still be useful, since a combination of MAbs specific to XSV and MrNV resulted in increasing detection sensitivity (Fig. 4G). In the case of co-infection of XSV with light infection of MrNV, WTD was detected and confirmed when using MAbs specific to MrNV and XSV together (Fig. 3). As for other viruses (W. Sithigorngul et al. 2006, 2007, P. Sithigorngul et al. 2011), MAbs targeted to different epitopes on the XSV CP in combination with the MAb generated recently (Wangman et al. 2012) to the MrNV CP should allow immunochromatographic strip tests to be developed for the rapid pond-side diagnosis of WTD.
Acknowledgements. This work was supported by the National Center for Genetic Engineering and Biotechnology (BIOTEC) Thailand to CENTEX Shrimp, Mahidol University. The authors are also indebted to farmers who provided WTD and normal prawn samples.

\section{LITERATURE CITED}

Arcier JM, Herman F, Lightner DV, Redman RM, Mari J, Bonami JR (1999) A viral disease associated with mortalities in hatchery-reared postlarvae of the giant freshwater prawn Macrobrachium rosenbergii. Dis Aquat Org 38:177-181

Bonami JR, Sri Widada J (2011) Viral diseases of the giant freshwater prawn Macrobrachium rosenbergii: a review. J Invertebr Pathol 106:131-142

> Bonami JR, Shi Z, Qian D, Sri Widada J (2005) White tail disease of the giant freshwater prawn, Macrobrachium rosenbergii: separation of the associated virions and characterization of $M r \mathrm{NV}$ as a new type of nodavirus. J Fish Dis 28:23-31

> Boonsanongchokying C, Sang-oum W, Sithigorngul P, Sriurairatana S, Flegel TW (2006) Production of monoclonal antibodies to polyhedrin of monodon baculovirus (MBV) from shrimp. ScienceAsia 32:371-376

Bradford MM (1976) A rapid and sensitive method for the quantification of microgram quantities of protein utilizing the principle of protein-dye binding. Anal Biochem 72:248-254

Chaivisuthangkura P, Tangkhabuanbutra J, Longyant S, Sithigorngul W, Rukpratanporn S, Menasveta P, Sithigorngul P (2004) Monoclonal antibodies against a truncated viral envelope protein (VP28) can detect white spot syndrome virus (WSSV) infections in shrimp. ScienceAsia 30:359-363

- Haridas DV, Pillai D, Manojkumar B, Nair CM, Sherief PM (2010) Optimisation of reverse transcriptase loop-mediated isothermal amplification assay for rapid detection of Macrobrachium rosenbergii nodavirus and extra small virus in Macrobrachium rosenbergii. J Virol Methods 167:61-67

Hsieh CY, Wu ZB, Tung MC, Tu C and others (2006) In situ hybridization and RT-PCR detection of Macrobrachium rosenbergii nodavirus in giant freshwater prawn, Macrobrachium rosenbergii (de Man), in Taiwan. J Fish Dis 29: 665-671

Köhler G, Milstein C (1976) Derivation of specific antibody producing tissue culture and tumor lines by cell fusion. Eur J Immunol 6:511-519

Kunanopparat A, Chaivisuthangkura P, Senapin S, Lonyant S, Rukpratanporn S, Flegel TW, Sithigorngul P (2011) Detection of infectious myonecrosis virus using monoclonal antibody specific to $\mathrm{N}$ and $\mathrm{C}$ fragments of the capsid protein expressed heterologously. J Virol Methods 171:141-148

Laemmli UK (1970) Cleavage of structural proteins during the assembly of the head of bacteriophage T4. Nature 227:680-685

Longyant S, Poyoi P, Chaivisuthangkura P, Tejankura T, Sithigorngul W, Sithigorngul P, Rukpratanporn S (2008) Specific monoclonal antibodies raised against Taura syndrome virus (TSV) capsid protein VP3 detect TSV in single and dual infections with white spot syndrome virus (WSSV). Dis Aquat Org 79:75-81 
Mosmann TR, Bauman R, Williamson AR (1979) Mutations affecting immunoglobulin light chain secretion by myeloma cells. I. Functional analysis by cell fusion. Eur J Immunol 9:511-516

> Owens L, La Fauce K, Juntunen K, Hayakijkosol O, Zeng C (2009) Macrobrachium rosenbergii nodavirus disease (white tail disease) in Australia. Dis Aquat Org 85: 175-180

Pillai D, Bonami JR, Sri Widada J (2006) Rapid detection of Macrobrachium rosenbergii nodavirus ( $\mathrm{MrNV}$ ) and extra small virus (XSV), the pathogenic agents of white tail disease of Macrobrachium rosenbergii (De Man), by loopmediated isothermal amplification. J Fish Dis 29:275-283

Puthawibool T, Senapin S, Kiatpathomchai W, Flegel TW (2010) Rapid and sensitive detection of Macrobrachium rosenbergii nodavirus in giant freshwater prawns by reverse transcription loop-mediated isothermal amplification combined with a lateral flow dipstick. Mol Cell Probes 24:244-249

Qian D, Shi Z, Zhang S, Cao Z and others (2003) Extra small virus-like particles (XSV) and nodavirus associated with whitish muscle disease in the giant freshwater prawn Macrobrachium rosenbergii. J Fish Dis 26:521-527

Qian D, Liu W, Jianxiang W, Yu L (2006) Preparation of monoclonal antibody against Macrobrachium rosenbergii nodavirus and application of TAS-ELISA for virus diagnosis in post-larvae hatcheries in east China during 2000-2004. Aquaculture 261:1144-1150

Romestand B, Bonami JR (2003) A sandwich enzyme linked immunosorbent assay (S-ELISA) for detection of $\mathrm{MrNV}$ in the giant freshwater prawn, Macrobrachium rosenbergii (de Man). J Fish Dis 26:71-75

Rukpratanporn S, Sukhumsirichart W, Chaivisuthangkura P, Longyant S, Sithigorngul W, Menasveta P, Sithigorngul P (2005) Generation of monoclonal antibodies specific to hepatopancreatic parvovirus (HPV) from Penaeus monodon. Dis Aquat Org 65:85-89

Sahul Hameed AS, Yoganandhan K, Sri Widada J, Bonami JR (2004) Studies on the occurrence of Macrobrachium rosenbergii nodavirus and extra small virus-like particles associated with white tail disease of $M$. rosenbergii in India by RT-PCR detection. Aquaculture 238:127-133

Sahul Hameed AS, Ravi M, Farook MA, Taju G, HernandezHerrera RI, Bonami JR (2011) Screening the post-larvae of Macrobrachium rosenbergii for early detection of Macrobrachium rosenbergii nodavirus (MrNV) and extra small virus (XSV) by RT-PCR and immunological techniques. Aquaculture 317:42-47

Senapin S, Molthathong S, Phiwsaiya K, Jaengsanong C, Chuchird N (2010) Application of high resolution melt (HRM) analysis for duplex detection of Macrobrachium rosenbergii nodavirus ( $M r N V)$ and extra small virus (XSV) in shrimp. Mol Cell Probes 24:291-297

Senapin S, Jaengsanong C, Phiwsaiya K, Prasertsri S and others (2012) Infections of MrNV (Macrobrachium rosenbergii nodavirus) in cultivated whiteleg shrimp Penaeus vannamei in Asia. Aquaculture 338-341:41-46

Sithigorngul P, Rukpratanporn S, Longyant S, Chaivisuthangkura P, Sithigorngul W, Menasveta P (2002) Monoclonal antibodies specific to yellow-head virus (YHV) of Penaeus monodon. Dis Aquat Org 49:71-76

Sithigorngul W, Rukpratanporn S, Pecharaburanin N, Longyant S, Chaivisuthangkura P, Sithigorngul P (2006) A simple and rapid immunochromatographic test strip

Editorial responsibility: Alex Hyatt,

Geelong, Victoria, Australia for detection of white spot syndrome virus (WSSV) of shrimp. Dis Aquat Org 72:101-106

Sithigorngul W, Rukpratanporn S, Sittidilokratna N, Pecharaburanin N, Longyant S, Chaivisuthangkura P, Sithigorngul P (2007) A convenient immunochromatographic test strip for rapid diagnosis of yellow head virus infection in shrimp. J Virol Methods 140:193-199

Sithigorngul $\mathrm{P}$, Rukpratanporn $\mathrm{S}$, Chaivisuthangkura $\mathrm{P}$, Sridulyakul P, Longyant S (2011) Simultaneous and rapid detection of white spot syndrome virus and yellow head virus infection in shrimp with a dual immunochromatographic strip test. J Virol Methods 173:85-91

Sri Widada J, Bonami JR (2004) Characteristics of the monocistronic genome of extra small virus, a virus-like particle associated with Macrobrachium rosenbergii nodavirus: possible candidate for a new species of satellite virus. J Gen Virol 85:643-646

- Sri Widada J, Durand S, Cambournac I, Qian D and others (2003) Genome-based detection methods of Macrobrachium rosenbergii nodavirus, a pathogen of the giant freshwater prawn Macrobrachium rosenbergii: dot-blot, in situ hybridization and RT-PCR. J Fish Dis 26:583-590

- Tang KFJ, Pantoja CR, Poulos BT, Redman RM, Lightner DV (2005) In situ hybridization demonstrates that Litopenaeus vannamei, L. stylirostris and Penaeus monodon are susceptible to experimental infection with infectious myonecrosis virus (IMNV). Dis Aquat Org 63:261-265

> Tang KFJ, Pantoja CR, Redman RM, Lightner DV (2007) Development of in situ hybridization and RT-PCR assay for the detection of a nodavirus $(P V N V)$ that causes muscle necrosis in Penaeus vannamei. Dis Aquat Org 75: 183-190

Tripathy S, Sahoo PK, Kumari J, Mishra BK, Sarangi N, Ayyappan S (2006) Multiplex RT-PCR detection and sequence comparison of viruses MrNV and XSV associated with white tail disease Macrobrachium rosenbergii. Aquaculture 258:134-139

Tung CW, Wang CS, Chen SN (1999) Histological and electron microscopic study on Macrobrachium muscle virus (MMV) infection in the giant freshwater prawn, Macrobrachium rosenbergii (de Man), cultured in Taiwan. J Fish Dis 22:1-5

> Wang CS, Chang JS, Wen CM, Shih HH, Chen SN (2008) Macrobrachium rosenbergii nodavirus infection in $M$. rosenbergii (de Man) with white tail disease cultured in Taiwan. J Fish Dis 31:415-422

> Wangman P, Senapin S, Chaivisuthangkura P, Longyant S, Rukpratanporn S, Sithigorngul P (2012) Production of monoclonal antibodies specific to Macrobrachium rosenbergii nodavirus using recombinant capsid protein. Dis Aquat Org 98:121-131

Yoganandhan K, Sri Widada J, Bonami JR, Sahul Hameed AS (2005) Simultaneous detection of Macrobrachium rosenbergii nodavirus and extra small virus by a single tube, one-step multiplex RT-PCR assay. J Fish Dis 28: 65-69

> Yoganandhan K, Leartvibhas M, Sriwongpuk S, Limsuwan C (2006) White tail disease of the giant freshwater prawn Macrobrachium rosenbergii in Thailand. Dis Aquat Org 69:255-258

> Zhang H, Wang J, Yuan J, Li L, Zhang J, Bonami JR, Shi Z (2006) Quantitative relationship of two viruses ( $M r N V$ and XSV) in white-tail disease of Macrobrachium rosenbergii. Dis Aquat Org 71:11-17

Submitted: November 28, 2011; Accepted: May 9, 2012

Proofs received from author(s): July 2, 2012 